\title{
The Identification of Potential Resilient Estuary-based Enterprises to Encourage Economic Empowerment in South Africa: a Toolkit Approach
}

\author{
$\underline{\text { Rebecca Bowd }}^{1}, \underline{\text { Nevil Quinn }}^{2}, \underline{\text { Donovan C.Kotze }}^{1}, \underline{\text { Duncan G. Hay }}^{3}$, and Myles Mander ${ }^{4}$
}

\begin{abstract}
It has been argued that ecosystem services can be used as the foundation to provide economic opportunities to empower the disadvantaged. The Ecosystem Services Framework (ESF) approach for poverty alleviation, which balances resource conservation and human resource use, has received much attention in the literature. However, few projects have successfully achieved both conservation and economic objectives. This is partly due to there being a hiatus between theory and practice, due to the absence of tools that help make the transition between conceptual frameworks and theory, to practical integration of ecosystem services into decision making. To address this hiatus, an existing conceptual framework for analyzing the robustness of social-ecological systems was translated into a practical toolkit to help understand the complexity of socialecological systems (SES). The toolkit can be used by a diversity of stakeholders as a decision making aid for assessing ecosystem services supply and demand and associated enterprise opportunities. The toolkit is participatory and combines both a generic "top-down" scientific approach with a case-specific "bottom-up" approach. It promotes a shared understanding of the utilization of ecosystem services, which is the foundation of identifying resilient enterprises. The toolkit comprises four steps: (i) ecosystem services supply and demand assessment; (ii) roles identification; (iii) enterprise opportunity identification; and (vi) enterprise risk assessment, and was tested at two estuary study sites. Implementation of the toolkit requires the populating of preprogrammed Excel worksheets through the holding of workshops that are attended by stakeholders associated with the ecosystems. It was concluded that for an enterprise to be resilient, it must be resilient at an external SES level,which the toolkit addresses, and at an internal business functioning level, e.g., social dynamics among personnel, skills, and literacy levels. Although the toolkit does not address the internal resilience level of an enterprise, it proved helpful at indicating which enterprises show potential resilience given current SES conditions.
\end{abstract}

Key Words: ecosystem services; participatory tools; risk assessment; social-ecological systems; stakeholder engagement

\section{INTRODUCTION}

In 2008 the South African Institute for Race Relations (SAIRR) recognized that the gap between the wealthy and the poor in South Africa was continuing to increase, and that this situation was not sustainable (Hunter et al. 2003, Meth and Dias 2004). Recent studies suggest South Africa's inequality levels are among the highest in the world (Fosu 2011) and during the period 1993-2008, income has been increasingly concentrated in the top decile (Leibbrandt et al. 2010). Rural communities experience relatively greater poverty (Leibbrandt et al. 2010), and nowhere is this more the case than the Eastern Cape Province of South Africa, where concern has been expressed, not just in relation to standard poverty metrics (Dzivakwi and Jacobs 2010), but also to people's vulnerability to poverty (Baiyegunhi and Fraser 2010).

It has been argued that ecosystem services can be employed as both a 'common language' for ecosystem-based management (Granek et al. 2009), and as the foundation to providing economic opportunities to empower the disadvantaged (MEA 2005). Although both the wealthy and the poor rely on the functioning of ecosystems (Batabyal and Yoo 1994, Scheffer et al. 2000, MEA 2005), the poor are often more directly reliant on these goods, services, and attributes than the affluent. As noted by Tallis et al. (2008:9459), "for the rural poor, at the local level, the status of ecosystem services can make a big difference in their daily lives."

The potential application of the Ecosystem Services Framework (ESF) approach for poverty alleviation, which balances resource conservation and use according to how society values consumptive and nonconsumptive services provided by an ecosystem, has received much attention in the literature (Brown et al. 2008, Shackleton et al. 2008, Tallis et al. 2008). The ESF approach is currently the focus of a significant research endeavor known as ESPA (Ecosystem Services for Poverty Alleviation see www.espa.ac.uk/). Other initiatives, such as the Natural Capital Project (see www.natu ralcapitalproject.org/home04.html) have also focused on the potential for aligning conservation and economics via the ESF (Turner and Daily 2008).

However, projects that have successfully achieved both conservation and economic objectives are relatively rare. For example, in an analysis of World Bank projects that had the dual aims of poverty alleviation and biodiversity conservation, Tallis et al. (2008) found that only $16 \%$ made significant progress on both objectives. Part of the reason for this has been the hiatus between theory and practice. As suggested by Turner

\footnotetext{
${ }^{1}$ School of Environmental Sciences, University of KwaZulu-Natal, ${ }^{2}$ Department of Geography and Environmental Management, University of the West of England, ${ }^{3}$ Independent Consultant, ${ }^{4}$ Eco-Futures
} 
and Daily (2008:25), despite this attention in the literature, "an operational decision support system" for implementing an ESF has been "slow to emerge." Daily and Matson (2008:9456) put the challenge more strongly, "(r)adical transformations will be required to move from conceptual frameworks and theory to practical integration of ecosystem services into decision-making, in a way that is credible, replicable, scalable and sustainable."

In this paper we attempt to address this challenge by presenting an approach for applying an ESF to assist in the identification of opportunities for economic empowerment at two estuary study sites in the Eastern Cape Province, South Africa. In doing so, we also provide an example of how an ESF can be used toward the aim of poverty alleviation.

\section{METHODS}

\section{Selection of study sites}

Estuaries, in particular, are a useful context in which to develop and test ideas regarding ESFs. Day (1980:198) defines an estuary as a "partially enclosed coastal body of water which is either permanently or periodically open to the sea, and within which there is a mixture of seawater with freshwater derived from land drainage." Estuaries are ecosystems comprised of a number of different habitats, such as mangroves, tidal flats, and reed beds, which can provide food, building material, and protection; are catalysts for residential, commercial, tourism, and recreational development; and can ameliorate floods and assimilate waste (Gunderson et al. 2006, Hay 2007, Barbier et al. 2011). Estuaries are therefore complex and dynamic social-ecological systems (SES; Anderies et al. 2004), where interactions occur between:

- ecological elements, e.g., fish eating crabs that eat algae, which grow on mangrove roots;

- ecological and human elements, e.g., humans abstracting freshwater upstream, which reduces fish productivity;

- human elements, e.g., provincial government building roads that allow local communities to visit estuaries.

In South Africa (Turpie and Clark 2007), and globally (Barbier et al. 2011), estuaries are clearly valuable economic, environmental, and social assets that can provide economic empowerment, including job creation for disadvantaged people living at or near them (Turpie and Clark 2007). Many of the services provided by estuaries are taken for granted and consequently the derived benefits are undervalued. Estuaries are highly dynamic environments that are unpredictable and erratic in nature. Given their high productivity, they are often subject to very high levels of use, and given their location in the lowermost point in the catchment, are often subject to some of the greatest anthropogenic impacts.

Estuaries are also common property resources with poorly defined property rights. This complicates the allocation of opportunities and the benefits that arise from these opportunities. Securing tenure, a vital necessity for most economic developments to succeed, requires a level of sophistication that is currently in short supply in many rural parts of South Africa.

Two estuaries located in the Eastern Cape Province of South Africa were chosen to apply the toolkit: the Umngazi estuary, located near Port St. John (3137'38.43"S, 29³2'58.44"E), and the Tyolomnqa estuary, located near East London $\left(32^{\circ}\right.$ $\left.58^{\prime} 56.85^{\prime \prime} \mathrm{S}, 27^{\circ} 56^{\prime} 52.70^{\prime \prime} \mathrm{E}\right)$. Both sites currently provide a variety of ecosystem services but differ with respect to their component social systems. The Tyolomnqa estuary's social system is large and complex, and comprises prominent local and provincial governmental bodies, nongovernmental agencies, and general service users, e.g., local and visiting fishermen. This system is in relatively close proximity to the urban center of East London, and the policing of resource use activities is high. In contrast, the Umngazi system is rural in nature and is less complex because there are fewer stakeholders. Although local and provincial governmental bodies operate in the area, their presence is not strong. The dominant stakeholders are the local community, a wellestablished hotel, and tourists.

\section{Criteria for developing the ESF Toolkit}

The overall aim of the ESF toolkit is to provide a structured mechanism for identifying potential estuary-based enterprises that take into consideration the dependence of human wellbeing on natural capital, and that consider resource conservation (Turner and Daily 2008). Turner and Daily (2008:26) identify three constraints in making an ESF approach operational. First there is what they describe as "information failure," which is the lack of detailed information about the way in which people benefit from ecosystem services, and at a scale that is relevant to decision makers. The second is "institutional failure." This arises as a result of the failure to consider local social-ecological contexts, including property rights and institutions, and the fact that those who benefit from ecosystem transformation are not the same as the recipients of ecosystem services. Finally "market failure" arises because of the public good nature of benefits and because many of the benefits cannot be quantified or measured in a single currency.

Turner and Daily's (2008) critique has therefore informed the identification of a set of four criteria that would be instrumental in a successful ESF approach. The first criterion is that public participation should be an integral part. This relates strongly to information failure and institutional failure constraints. Second, it is evident that one of the fundamental attributes of an operational ESF should be a mechanism that allows the particular services to be discussed, understood, and valued in a common currency. In other words the ESF should provide a platform for discussion by contributing detailed information on ecosystem services. Third the toolkit must have the ability 
to gauge a system's resilience because the purpose of this study is to have a framework that identifies potential resilient estuary-based enterprises. Finally, the toolkit must contribute to obtaining a thorough understanding of the complex socialecological context. This too would help address the institutional failure and the market failure constraints.

\section{An ESF Toolkit for economic empowerment must be participative}

In recent years stakeholder engagement has moved from being a marginal concern to a driving force (Lynam et al. 2007). Furthermore a dichotomy has been recognized between the commonly used "top-down" generic scientific tools that are frequently developed without input from the local stakeholders, and the case-specific customized "bottom-up" tools that are generally driven by local needs (Fall and Fall 2001, Sturtevant et al. 2007). Gunderson et al. (2006) identify five factors for constructive communication to take place: (1) the development and maintenance of open communication channels (Berkes et al. 1998, Folke et al. 2005); (2) identification of the roles of the different stakeholders through scientific activities or social communication (Fazey et al. 2005); (3) the designation of a meeting place at which discussions can take place between the different stakeholders; (4) the establishment of trust between the stakeholders; and (5) the establishment of leadership because this is required to integrate social and ecological understanding, and to delegate responsibility to ensure that progress is made. Participation characterized by constructive communication must therefore be a central criterion.

\section{An ESF Toolkit for economic empowerment must provide detailed information on ecosystem services}

An early challenge in the ecosystem services debate was defining and categorizing the nature and scope of these services. For example, Hein et al. (2006) present a generically applicable framework based on earlier contributions (Pearce and Turner 1990, Costanza and Folke 1997, de Groot et al. 2002, MEA 2003). This framework defines three types of services, i.e., production, regulation, and cultural. Production services refer to goods and services produced in an ecosystem, e.g., food, fuel timber; regulation services result from the capacity of ecosystems to regulate a variety of biological processes, e.g., erosion, storm protection; and cultural services relate to the benefits people obtain from ecosystems through recreation, cognitive development, relaxation, and spiritual reflection. It differs from the Millennium Ecosystem Assessment (MEA 2003), in that it does not differentiate supporting services. Supporting services represent the ecological processes that underlie the functioning of an ecosystem, and Hein et al. (2006) are of the opinion that the inclusion of supporting services could result in the "double counting" of services, and thus affect the valuation because they will feature in one of the other three types of services. The Resilience Alliance (2010) modified the Hein et al. (2006) framework by adding "regeneration services" to the regulation services. This was done to emphasize the importance of services, such as soil fertility maintenance (Resilience Alliance 2010).

In South Africa much work on describing and classifying estuary ecosystem services has been conducted. Turpie and Clark (2007) document estuary associated goods, services, and attributes and define goods as harvested resources, such as fish, services as processes that contribute to economic production or save costs, such as water purification, and attributes as relating to the structure and organization of biodiversity, such as beauty, rarity, or diversity, that generate less tangible benefits, such as spiritual, educational, cultural, and recreational values.

Based on these contributions a comprehensive list of estuary ecosystem services was developed. The term 'services' has been used to encompass goods, services, and attributes, as per Hein et al. (2006), Resilience Alliance (2010), and Bowd et al. (2012). Each of these services is related to the presence of suitable estuary habitat(s) and consequently it was important to identify the full range of estuary habitats. From conducting a brief literature review on the ecological functioning of South African estuaries, it became apparent that 10 habitat types could be identified (Branch and Grindley 1979, Allanson 1981, Baird 1999, Colloty et al. 2002), each of which was associated with one or more services (Table 1).

\section{An ESF Toolkit for economic empowerment must consider resilience}

Because all ecosystem services are subject to the influences of natural and anthropogenic processes that are highly variable, supplies of services are seldom uniform. Although some services may seem to be constant over time, others can exhibit wide variations, even over short time scales. Thus every enterprise that is founded on ecosystem services must anticipate changes over time and space as a consequence of both natural and human influences. Some of these influences may be controlled by society, e.g., pollution, however others, e.g., large floods, cannot. The viability of ecosystem-based enterprises will equally be influenced by fluctuations in the demand for services (see Baumgärtner et al. 2011 for an interesting discussion on the relationship between consumer preferences and resilience of ecological-economic systems). These demands may be very variable over time and in space, and furthermore, not all demands are compatible. Neither can they necessarily be accommodated at the same time, and in the same place. This lack of control of interaction places resilience at the forefront of conceptualizing, designing, establishing, and operating estuary-based enterprises. We define resilient estuary-based enterprises as those that are able to continue profitably under conditions of varying supply of, and demand for, the services upon which they are dependent. Necessarily this needs to be contextualized within the broader 
Table 1. Comprehensive list of estuary habitats and associated ecosystem services found in South Africa $(\mathrm{Y}=\mathrm{yes}, \mathrm{N}=\mathrm{no})$.

\begin{tabular}{|c|c|c|c|c|c|c|c|c|c|c|}
\hline \multirow[t]{2}{*}{ Ecosystem Services } & \multicolumn{10}{|c|}{ Estuary Habitats } \\
\hline & $\begin{array}{c}\text { River } \\
\text { estuary } \\
\text { interface }\end{array}$ & Mangroves & Reedbeds & $\begin{array}{c}\text { Salt } \\
\text { marshes }\end{array}$ & $\begin{array}{c}\text { Open } \\
\text { water \& } \\
\text { water } \\
\text { column }\end{array}$ & $\begin{array}{c}\text { Intertidal } \\
\text { banks }\end{array}$ & $\begin{array}{c}\text { Intertidal } \\
\text { flats }\end{array}$ & $\begin{array}{c}\text { Temporarily } \\
\text { submerged } \\
\text { sediments }\end{array}$ & $\begin{array}{c}\text { Permanently } \\
\text { submerged } \\
\text { sediments }\end{array}$ & $\begin{array}{c}\text { Estuary } \\
\text { mouth }\end{array}$ \\
\hline
\end{tabular}

Goods

\begin{tabular}{|c|c|c|c|c|c|c|c|c|c|c|}
\hline Bait harvesting & $\mathrm{N}$ & $\mathrm{Y}$ & $\mathrm{N}$ & $\mathrm{Y}$ & $\mathrm{Y}$ & $\mathrm{Y}$ & $\mathrm{Y}$ & $\mathrm{Y}$ & $\mathrm{N}$ & $\mathrm{Y}$ \\
\hline Fibres & Y & $\mathrm{Y}$ & $\mathrm{Y}$ & $\mathrm{Y}$ & $\mathrm{N}$ & Y & $\mathrm{N}$ & $\mathrm{N}$ & $\mathrm{N}$ & $\mathrm{N}$ \\
\hline Food & $\mathrm{Y}$ & $\mathrm{Y}$ & $\mathrm{Y}$ & $\mathrm{Y}$ & $\mathrm{Y}$ & $\mathrm{Y}$ & $\mathrm{Y}$ & $\mathrm{Y}$ & $\mathrm{Y}$ & $\mathrm{Y}$ \\
\hline Minerals & $\mathrm{Y}$ & $\mathrm{Y}$ & $\mathrm{Y}$ & $\mathrm{Y}$ & $\mathrm{N}$ & $\mathrm{Y}$ & $\mathrm{Y}$ & $\mathrm{Y}$ & $\mathrm{Y}$ & $\mathrm{N}$ \\
\hline Nursery for fish / crustacean species & $\mathrm{Y}$ & $\mathrm{Y}$ & $\mathrm{Y}$ & $\mathrm{Y}$ & $\mathrm{Y}$ & $\mathrm{Y}$ & $\mathrm{Y}$ & $\mathrm{Y}$ & $\mathrm{Y}$ & $\mathrm{N}$ \\
\hline Sediment supply & $\mathrm{N}$ & $\mathrm{Y}$ & $\mathrm{Y}$ & $\mathrm{Y}$ & $\mathrm{N}$ & $\mathrm{Y}$ & $\mathrm{Y}$ & $\mathrm{Y}$ & $\mathrm{Y}$ & $\mathrm{Y}$ \\
\hline \multicolumn{11}{|l|}{ Services } \\
\hline Boat launching and transport & $\mathrm{Y}$ & $\mathrm{N}$ & $\mathrm{N}$ & $\mathrm{N}$ & $\mathrm{Y}$ & $\mathrm{Y}$ & $\mathrm{N}$ & $\mathrm{N}$ & $\mathrm{N}$ & $\mathrm{Y}$ \\
\hline Disease control & $\mathrm{Y}$ & $\mathrm{Y}$ & $\mathrm{Y}$ & $\mathrm{Y}$ & $\mathrm{Y}$ & Y & $\mathrm{Y}$ & $\mathrm{Y}$ & $\mathrm{Y}$ & $\mathrm{Y}$ \\
\hline Flood and storm flow attenuation & $\mathrm{Y}$ & $\mathrm{Y}$ & $\mathrm{Y}$ & $\mathrm{Y}$ & $\mathrm{Y}$ & $\mathrm{Y}$ & $\mathrm{Y}$ & $\mathrm{N}$ & $\mathrm{N}$ & $\mathrm{Y}$ \\
\hline Pest control & $\mathrm{Y}$ & $\mathrm{Y}$ & $\mathrm{Y}$ & $\mathrm{Y}$ & $\mathrm{Y}$ & $\mathrm{Y}$ & $\mathrm{Y}$ & $\mathrm{Y}$ & $\mathrm{Y}$ & $\mathrm{Y}$ \\
\hline Waste assimilation & $\mathrm{Y}$ & $\mathrm{Y}$ & $\mathrm{Y}$ & $\mathrm{Y}$ & $\mathrm{Y}$ & Y & $\mathrm{Y}$ & $\mathrm{Y}$ & $\mathrm{Y}$ & $\mathrm{N}$ \\
\hline Waste dilution & $\mathrm{Y}$ & $\mathrm{Y}$ & $\mathrm{Y}$ & $\mathrm{Y}$ & $\mathrm{Y}$ & $\mathrm{N}$ & $\mathrm{N}$ & $\mathrm{N}$ & $\mathrm{Y}$ & $\mathrm{Y}$ \\
\hline Wind damage control & $\mathrm{N}$ & $\mathrm{Y}$ & $\mathrm{Y}$ & $\mathrm{Y}$ & $\mathrm{N}$ & $\mathrm{Y}$ & $\mathrm{N}$ & $\mathrm{N}$ & $\mathrm{N}$ & $\mathrm{N}$ \\
\hline \multicolumn{11}{|l|}{ Attributes } \\
\hline Angling & $\mathrm{Y}$ & $\mathrm{Y}$ & $\mathrm{Y}$ & $\mathrm{N}$ & $\mathrm{Y}$ & Y & $\mathrm{Y}$ & $\mathrm{Y}$ & $\mathrm{Y}$ & $\mathrm{Y}$ \\
\hline Birding & $\mathrm{Y}$ & $\mathrm{Y}$ & $\mathrm{Y}$ & $\mathrm{Y}$ & $\mathrm{Y}$ & $\mathrm{Y}$ & $\mathrm{Y}$ & $\mathrm{Y}$ & $\mathrm{N}$ & $\mathrm{Y}$ \\
\hline Canoeing & $\mathrm{Y}$ & $\mathrm{Y}$ & $\mathrm{Y}$ & $\mathrm{N}$ & $\mathrm{Y}$ & $\mathrm{Y}$ & $\mathrm{Y}$ & $\mathrm{N}$ & $\mathrm{N}$ & $\mathrm{Y}$ \\
\hline Cultural places & $\mathrm{Y}$ & $\mathrm{Y}$ & $\mathrm{Y}$ & $\mathrm{Y}$ & $\mathrm{Y}$ & $\mathrm{Y}$ & $\mathrm{Y}$ & $\mathrm{Y}$ & $\mathrm{N}$ & $\mathrm{Y}$ \\
\hline General recreation & $\mathrm{Y}$ & $\mathrm{Y}$ & $\mathrm{Y}$ & $\mathrm{Y}$ & $\mathrm{Y}$ & Y & $\mathrm{Y}$ & $\mathrm{N}$ & $\mathrm{N}$ & $\mathrm{Y}$ \\
\hline $\begin{array}{l}\text { Knowledge generation and learning } \\
\text { sites }\end{array}$ & $\mathrm{Y}$ & $\mathrm{Y}$ & $\mathrm{Y}$ & $\mathrm{Y}$ & $\mathrm{Y}$ & $\mathrm{Y}$ & $\mathrm{Y}$ & $\mathrm{Y}$ & $\mathrm{Y}$ & $\mathrm{Y}$ \\
\hline Natural Heritage & $\mathrm{Y}$ & $\mathrm{Y}$ & $\mathrm{Y}$ & $\mathrm{Y}$ & $\mathrm{Y}$ & $\mathrm{Y}$ & $\mathrm{Y}$ & $\mathrm{Y}$ & $\mathrm{Y}$ & $\mathrm{Y}$ \\
\hline Sailing & $\mathrm{N}$ & $\mathrm{N}$ & $\mathrm{N}$ & $\mathrm{N}$ & $\mathrm{Y}$ & $\mathrm{N}$ & $\mathrm{Y}$ & $\mathrm{N}$ & $\mathrm{N}$ & $\mathrm{Y}$ \\
\hline Settlement & $\mathrm{Y}$ & $\mathrm{N}$ & $\mathrm{N}$ & $\mathrm{N}$ & $\mathrm{Y}$ & $\mathrm{N}$ & $\mathrm{N}$ & $\mathrm{N}$ & $\mathrm{N}$ & $\mathrm{N}$ \\
\hline Visual amenity & $\mathrm{Y}$ & $\mathrm{Y}$ & $\mathrm{Y}$ & $\mathrm{Y}$ & $\mathrm{Y}$ & $\mathrm{Y}$ & $\mathrm{Y}$ & $\mathrm{N}$ & $\mathrm{N}$ & $\mathrm{Y}$ \\
\hline Swimming & $\mathrm{Y}$ & $\mathrm{N}$ & $\mathrm{N}$ & $\mathrm{N}$ & $\mathrm{Y}$ & $\mathrm{Y}$ & $\mathrm{Y}$ & $\mathrm{N}$ & $\mathrm{Y}$ & $\mathrm{Y}$ \\
\hline Skiing & $\mathrm{N}$ & $\mathrm{N}$ & $\mathrm{N}$ & $\mathrm{N}$ & Y & $\mathrm{N}$ & Y & $\mathrm{N}$ & $\mathrm{N}$ & $\mathrm{N}$ \\
\hline
\end{tabular}

debate around resilience, adaptability, and transformability in social-ecological systems (Walker et al. 2004, Folke et al. 2010).

Since the 1970 s a variety of definitions and interpretations of resilience have appeared (Pimm 1991, Grimm and Wissel 1997, Neubert and Caswell 1997, Walker et al. 2004). Ecological resilience is generally defined as the amount of disturbance that a system can absorb without a change in its state, usually defined by its structure and composition (Carpenter et al. 2001, Walker et al. 2006, Holling 2010). A resilient estuarine system is a system that can continue to provide the necessary services, which are utilized by the different stakeholders, even after times of stress, e.g., ecological conditions allow fish stocks to recover after extensive fishing during the previous season.

An estuary can be impacted upon by both natural events and human actions, which include human interventions that occur in response to natural events, e.g., implementation of bank stabilization measures. For an estuary to be considered resilient it must retain its state. Because an estuary supplies a wide range of services to a variety of stakeholder groups, it is unlikely that at any one time, there will be consensus among the different stakeholders that an estuary has retained its state, and is thus resilient.

There were a number of reasons why the concept of resilience was seen as being key to the approach. First, resilience has been applied widely to SESs and is increasingly being used to help understand, manage, and govern complex SESs (Walker et al. 2002, Anderies et al. 2004, Folke et al. 2004, Ostrom 2007). For example, it has been applied to political ecology and resource management (Berkes et al. 1998, Berkes 1999), as well as to a variety of specific ecosystems that include: rangelands (Anderies 2002, Janssen et al. 2004); lakes and wetlands (Gunderson 2001, Olsson et al. 2004); coral reefs (Hughes et al. 2005); a protected area (Newton 2011); and an evolving urban system (Bures and Kanapaux 2011). 
Fig. 1. Adaptation of the Anderies et al. (2004) conceptual social-ecological system framework showing (i) examples of how it relates to an estuarine system as presented in R. Bowd, N. W. Quinn, D. C. Kotze, D. G. Hay, and M. Mander (unpublished manuscript); and (ii) how the toolkit links with the Anderies et al. (2004) framework in which Step 1 - ecosystem services supply and demand assessment; Step 2 - future estuary roles identification; Step 3 - enterprise opportunity identification; Step 4 - enterprise risk assessment.

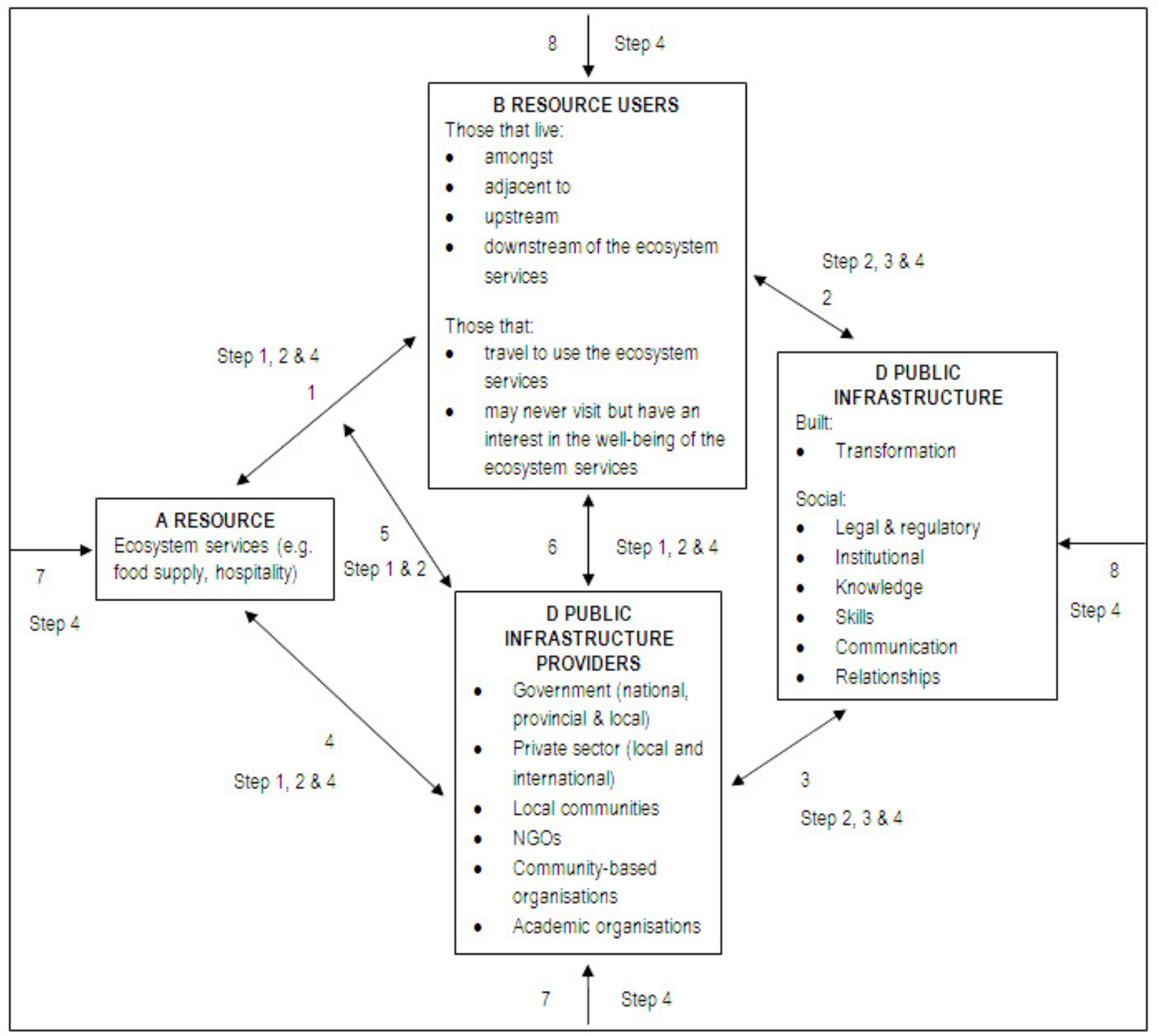

Second, resilience theory suggests that the major entities of an SES, and the level at which they interact, are identified through approaches that involve constructive communication between experts and stakeholders who understand the SES at different scales and perspectives (Walker et al. 2002, Westley et al. 2002). Third, resilience theory emphasizes the need to consider human adaptability (Gunderson and Holling 2002,
Walker et al. 2006). Human adaptability is the capacity of humans to manage for resilience; indeed collective capacity to manage resilience ultimately determines the future state of the SES (Walker et al. 2004). Human adaptability is therefore key in assessing the resilience of an enterprise and the SES on which an enterprise is dependent. Transformability has been defined as the "capacity to create a fundamentally new system 
Table 2. Entities involved in social-ecological systems together with examples and potential problems as identified by Anderies et al. (2004).

\begin{tabular}{lll}
\hline \hline Entities & Examples & Potential problems \\
\hline A. Resource & Water source & Uncertainty \\
& Fishery & Complexity/uncertainty \\
B. Resource users & Farmers using irrigation & Stealing water, getting a free ride on maintenance \\
& Fishers harvesting from inshore fishery & Over harvesting \\
C. Public infrastructure & Executive and council of local users' association & Internal conflict or indecision about which polices to adopt \\
providers & Government bureau & Information loss \\
$\begin{array}{ll}\text { D. Public infrastructure } \\
\text { Institutional rules }\end{array}$ & Engineering works & Wear out over time \\
External environment & Wemory loss over time, deliberate cheating & -
\end{tabular}

when ecological, economic, or social (including political) conditions make the existing system untenable" (Walker et al. 2004). This includes "introducing new components and new ways of making a living" that define the nature of the SES (Walker et al. 2004), so the concept is particularly relevant in defining resilient estuary-based enterprises.

\section{An ESF Toolkit for economic empowerment must accommodate complex social-ecological contexts}

Folke et al. (2010) argue that social-ecological resilience is concerned with the interdependence of people and nature, and furthermore that an ability to effect social change is necessary for SES resilience. The implication of this is that not only do we need to understand the present nature of the SES, but also how this SES might adapt or transform in the future. We show how an existing framework can be used to establish these relationships and use them in a process of social learning. Anderies et al. (2004) present a framework for analyzing the robustness of SESs from an institutional perspective. This framework provides a mechanism for disaggregating the entities of a SES and promotes the identification of the relationships between the different entities. The SES is separated into the following four entities (1) the resource, (2) the resource users, (3) public infrastructure, and (4) public infrastructure providers, and considers two types of disturbance, external and internal (Fig. 1). Table 2 provides examples of each of these entities, together with the typical management challenges that characterize them, whereas Table 3 explores the links between each entity and their associated problems. Tables 2 and 3 are taken directly from Anderies et al. (2004). Although the Anderies et al. (2004) approach is based on robustness and not resilience, we do not need to distinguish between the two because we consider robustness and resilience to have the same attributes for the purposes of this study.

\section{Developing the ESF Toolkit: structure}

The toolkit comprises four steps that are supported using a preprogrammed Excel worksheet, linked with the four entities of the Anderies et al. (2004) framework (Fig. 1). The Excel worksheet and toolkit manual have been published by the South African Water Research Commission (Bowd et al. 2012).

Step 1: ecosystem services supply and demand assessment This step requires that the estuary habitats present are confirmed and their functionality assessed. The functionality, and thus health, of an estuary's habitats is directly related to its ability to supply ecosystem services. To identify the estuary habitats, the boundaries of the SES first need to be identified, e.g., areas accessible on foot from the estuary mouth. The functionality of each of the habitats is then calculated, by assessing its condition $(0-3$, three being the best condition), size (area given in ha), and prominence of the ecosystem within the landscape $(0-3$, three being the most prominent). Although condition and size are the key determinants of service levels, the landscape context is less important and thus only weighted at $10 \%$ of the other two scores in the functionality calculation.

Next, the level of supply of the ecosystem services associated with each of the different habitats is scored $(0-3$, three being high, 0 being no supply). The scores are given as if the habitats are pristine. The service supply score is then multiplied by the functionality score, to give a relative service supply level for each service. It is recommended that the issue of seasonal variations in the supply of services is raised before scoring commences. It may be assumed that those services that have a high overall supply level are the services that enterprises should be based around.

Whereas the previous is concerned with the supply of services, the next focuses on the potential demand for services. Service demand at the local, downstream, provincial, and national and international levels are estimated. Estimated figures of users are shown as orders of magnitude (e.g. 0, 100, 1000). Following this the users of the services are listed, followed by the dependence of each of the different services being scored between 0 (no impact on welfare) and 3 (critical for welfare). 
Table 3. Links between the different entities within social-ecological systems, together with examples and potential problems as defined by Anderies et al. (2004).

\begin{tabular}{|c|c|c|}
\hline Link & Examples & Potential problems \\
\hline (1) Between resource and resource users & $\begin{array}{l}\text { Availability of water at time of need/availability of } \\
\text { fish }\end{array}$ & $\begin{array}{l}\text { Too much or too little water/too many uneconomic } \\
\text { fish— too many valued fish }\end{array}$ \\
\hline \multirow{4}{*}{$\begin{array}{l}\text { (2) Between users and public infrastructure } \\
\text { providers }\end{array}$} & Voting for providers & Indeterminacy/lack of participation \\
\hline & Contributing resources & Free riding \\
\hline & Recommending policies & Rent seeking \\
\hline & Monitoring performance of providers & Lack of information/free riding \\
\hline \multirow{3}{*}{$\begin{array}{l}\text { (3) Between public infrastructure providers } \\
\text { and public infrastructure }\end{array}$} & Building initial physical structure & Overcapitalization or undercapitalization \\
\hline & Regular maintenance & $\begin{array}{l}\text { Disrupting, temporal and spatial patterns of resource } \\
\text { use }\end{array}$ \\
\hline & Monitoring and enforcing rules & Cost/corruption \\
\hline $\begin{array}{l}\text { (4) Between public infrastructure and } \\
\text { resource }\end{array}$ & Impact of infrastructure on the resource level & Ineffective \\
\hline $\begin{array}{l}\text { (5) Between public infrastructure and } \\
\text { resource dynamics }\end{array}$ & $\begin{array}{l}\text { Impact of infrastructure on the feedback structure of } \\
\text { resource-harvest dynamics }\end{array}$ & Ineffective, unintended consequences \\
\hline $\begin{array}{l}\text { (6) Between resource users and public } \\
\text { infrastructure }\end{array}$ & $\begin{array}{l}\text { Coproduction of infrastructure itself, maintenance of } \\
\text { works, monitoring and sanctioning }\end{array}$ & No incentives/free riding \\
\hline $\begin{array}{l}\text { (7) External forces on resource and } \\
\text { infrastructure }\end{array}$ & Severe weather, earthquake, landslide, new roads & Destroys resource and infrastructure \\
\hline (8) External forces on social actors & $\begin{array}{l}\text { Major changes in political system, migration, } \\
\text { commodity prices, and regulation }\end{array}$ & $\begin{array}{l}\text { Conflict, uncertainty, migration, greatly increased } \\
\text { demand }\end{array}$ \\
\hline
\end{tabular}

As the toolkit is presented in a preprogrammed Excel worksheet, the following information is automatically calculated for each service: total supply score, total number of beneficiaries, average dependency, total demand summary, and combined total score. These data are then consolidated for use in Step 2.

\section{Step 2: future estuary roles identification}

The endpoint of the previous step is a ranking, in order of priority, of services that currently have high supply and low demand at a local, downstream, provincial, and national and international level. Using the knowledge and common understanding of the status quo gained though implementing Step 1, the desired roles for the estuary and possible conflicting uses, at local, downstream, provincial, and national and international levels, are then determined through discussion. Where supply is low, either intrinsically or because of poor ecological condition, but demand is high should be identified because this could indicate potential management actions that in themselves could represent enterprises, e.g., restoration.

\section{Step 3: enterprise opportunity identification}

The worksheet associated with this step provides space to document discussions around current and desired roles of the estuary, and possible conflicting uses. The worksheet provides different types of service use and possible estuary management categories to assist with identifying possible enterprise opportunities.

\section{Step 4: enterprise risk assessment}

This step is supported by two worksheets and is conducted for each enterprise. This step consists of a variety of questions that demonstrate the nature of possible relationships that may operate among the four entities of a SES (as identified by Anderies et al. 2004). Also included in this matrix are the external biophysical, social, and economic forces that may generate perturbations in a SES. The questions are based on those compiled by R. Bowd, N. W. Quinn, D. C. Kotze, D. G. Hay, and M. Mander (unpublished manuscript) who used the Anderies et al. (2004) framework to develop an analytical framework for understanding complex SES when conducting Environmental Impact Assessments in South Africa (Table 4).

The first worksheet requires that the severity and likelihood of each risk is scored ( $0-3$, three being very severe). A risk with a high severity of impact and a high likelihood of occurrence is considered to pose a major risk to enterprise resilience. The severity and likelihood scores are then summed to provide a semiquantitative value for each risk.

The second worksheet automatically ranks the risks according to the magnitude of risks identified previously. Once ranked, the priority risks are then assessed and mitigating actions identified and noted. If severe risks cannot be mitigated, then the proposed enterprise has a strong possibility of failure.

\section{TESTING THE TOOLKIT}

As recommended by Pickett et al. (1999), Scheffer et al. (2000), Anderies et al. (2006), and Sturtevant et al. (2007), a multidisciplinary team was involved in developing and testing the approach, including ecological, economic, and social scientists. Criteria 2 and 4 encourage the involvement of a diverse team. The opinions from the different disciplines 
Table 4. Risk Assessment (source: Bowd et al. 2012).

\begin{tabular}{l}
\hline Relationships \\
Relationship between resources users \\
Could some resource users deplete the resource and are they reliant on the resource, thus making it \\
difficult to change patterns of use? \\
Are there current conflicts between and/or within the different user groups? \\
Is the resource and its available services located within a clearly defined spatial boundary that can \\
exclude users without legal rights? \\
Are the people with rights to resource use a clearly defined group separate to those without rights of \\
resource use?
\end{tabular}
resource use?

Does everybody in the community with user rights participate in the resource use?

Are there good relationships between all the users who have a right of use?

The infrastructure, economic, social, and institutional assets available

To what extent is the built infrastructure developed and maintained?

Considering current infrastructure, is user safety secure all year round?

Does the built infrastructure meet current demand for access (the type, size, and quality of infrastructure)?

What are the levels of skills (education, knowledge, communication, hospitality) among the resource users?

What are the levels of skills (education, knowledge, communication, hospitality) among the resource managers/government?

How adaptable are the resource users to (i) changes in the availability of the resource; (ii) changes in demand; (iii) pursuing other activities to sustain livelihoods, etc.?

What rules of law (local, provincial, national, international) are applicable to the resource users?

To what extent are these rules of law enforced?

To what degree are cellular, telephone, email, and fax facilities available to the resource users; and to what degree are these facilities necessary?

Resources for management

To what degree is government contributing to the management of resource users with regard to: (i) the resource; (ii) research; (iii) infrastructure; (iv) skills/knowledge; (v) security; (vi) communication? Impact of infrastructure on resource levels

What are the impacts of (i) knowledge/skills; (ii) infrastructure; (iii) security/governance; and (vi) communication on the resource?

Policy implications

What policies are applicable to the resource users and what implications do these policies have on the resource users?

To what extent do these policies give (i) adequate protection to the resource; (ii) give adequate security, i.e., access, availability, of the resource to the resource users?

Integrated implementation of developments

Are there conflicts between government actions and/or government infrastructure?

Monitoring the state of the asset

To what extent is the state of the resource monitored and who is responsible for this monitoring?

Is there evidence of monitoring, and if so to what extent, are the findings of any monitoring efforts used to evaluate management, and thus influence future actions (adaptive management)?

Comanagement of built or natural assets

How adequate is the cooperation between the resource users and government to manage the (i) built environment; (ii) social/cultural environment; (iii) natural environment?

Can upstream resource users, who may influence the ecosystem functioning, and therefore the supply levels of services, be excluded or influenced?

Capacity and competency to implement policy

What policies are applicable to public and private infrastructure and to what degree are these policies implemented?

Intergovernment communication

Is there sufficient communication between different government tiers and departments?
Nature of the risk

Resource depletion

Inability to manage excessive resource utilization

Cannot enforce the right of exclusive use by owners

Cannot enforce the right of exclusive use by owners

Unequal incentives for community to manage the resource

Prohibitive transaction costs in establishing resource management

Poor quality infrastructure can limit access

Threat to personal security

Unsatisfactory access to the site

Inadequate skills to anticipate and resolve problems

Inadequate skills to anticipate and resolve problems

Poor adaptability to change

Partial application of laws

Uncertainty for investors and users regarding their investments

Poor communications - no access to market

Public services not being supplied to management - with risks to resource depletion

Depleted resources

Lack of investors

Diminished access to resources

Reduced or limited access to enterprise inputs

Inadequate knowledge for effective resource management

Management is not responsive to changes

Poor operating environment for enterprise heightened uncertainty for entrepreneurs

Asset can be run-down - with diminish services availability

No support for enterprises from government

High costs to do business 
Droughts, floods, changes in supply of resource services

What is the nature of severe biophysical impacts on the resource and what is the significance and frequency of these impacts?

Disregard for resource fluctuations

To what degree do resource users plan for fluctuations, and is this planning adequate?

Droughts, floods, wash-aways, destroyed communications

To what degree do external shocks damage public infrastructure with regards to: knowledge, skills, aids, natural disasters, over exploitation of resource, establishment or nonmaintenance of infrastructure, communication?

To what degree are these external shocks managed/prepared for, i.e., insurance, forward planning? Poverty and affluence - over use and exclusion

To what extent does poverty and/or affluence influence/affect overuse and exclusion of the resource? Can one user group's actions reduce the levels of services available to a different user group?

Do high transaction costs exclude key stakeholders from the decision making process?

Conflict, crime, uncertainty, changes in demand

Are there social and economic forces, such as conflict, crime (internal and external), and interest rates which can limit the demand by the resource users?

Have the rules of resource use and benefit sharing been understood and agreed to by all people who have rights of use before use commences?

Increased use pressures

Are there external social and economic forces, e.g., water provision, housing, creating pressure on available infrastructure that impacts on natural resource-based enterprises?

Effectiveness of governance

Does government have capacity/skills to cope with social and economic shocks to resource linked assets (resource, access, infrastructure)?

Are the rules of access and management duties well understood by all resource users?
Inability to supply services demanded

Insufficient revenue to cover costs

Prevention of clients accessing the enterprise site or threats to user safety

Insufficient revenue to cover costs

Asset can be run-down, diminish services Asset can be run-down, diminish services Unequal incentives to manage the resource

Reduced numbers of clients

Effort can be unrewarded - abandonment of enterprise

Asset can be run-down, diminish services

Prevention of clients accessing the enterprise or threat to personal safety or security Asset can be run-down, diminish services helped gain a comprehensive and common understanding of the different ecosystem services, and different aspects of the SES.

Criterion 1 highlights the importance of a participative approach, and as such the toolkit is primarily based on stakeholder engagement. Leemans (2000) identified stakeholder groups at a number of different levels. For the implementing and testing phase we adopted the following:

- Individual, family, and municipal stakeholders were grouped as 'local level' stakeholders; knowledge from this group is considered invaluable when obtaining a sound understandings of the dynamics of a SES (Olsson et al. 2004);

- A downstream level of stakeholder was introduced; this group refers to those who utilize services that could be negatively affected by activities upstream. This group is likely to be individuals and families, however in some instances it may include international, national, provincial, and municipal level stakeholders;

- Provincial and national level stakeholders, including government departments, e.g., National Department of Environmental Affairs;

- International level stakeholders, including international conservation nongovernmental organizations, e.g., World Wildlife Fund.

Walker (1992) believed that the greater the diversity of stakeholders involved in a process, the greater the chance of understanding the resilience of a system. This mix of stakeholder groups comprises the social component of the SES, and thus contributes to addressing criteria 3 and 4.

The toolkit was applied at Umngazi over two 2-day workshops, and at Tyolomnqa over one 2-day workshop. A full suite of stakeholders were identified through discussions with key stakeholders in the relevant areas, i.e., government departments, established enterprise owners, and review of estuary-related reports commissioned by the South African Water Research Commission. The identified stakeholders were personally invited to the workshop by phone, post, or email. At both study sites a wide variety of stakeholders attended and actively participated in the workshops (Table 5).

At each study site the first step was to define the boundaries of the SES. This helped gain a collective understanding of the SES among the different stakeholders (and helped address criterion 4). This was done by the stakeholders visiting the estuarine system and then continuing on to discuss the success and failure of past and present estuary-based enterprises, possible reasons for this success or failure, the supply and demand of the estuary services, and potential enterprise opportunities. Site visits facilitated a greater understanding of the system being considered, and promoted a shared understanding of the different ecosystem services provided by the estuary (Deconchat et al. 2007). The site visit and discussions contributed to addressing criterion 2 .

Following the site visits, workshops for the stakeholders were held where the project team methodically introduced and applied the toolkit. Although the toolkit provided structured 
Table 5. Concise results from testing the toolkit at Umngazi estuary and the Tyolomnqa estuary workshops.

\begin{tabular}{|c|c|c|c|c|}
\hline & \multicolumn{2}{|c|}{ Umngazi Estuary } & \multicolumn{2}{|c|}{ Tyolomnqa Estuary } \\
\hline $\begin{array}{l}\text { Representatives present: } \\
\text { National government }\end{array}$ & \multicolumn{2}{|c|}{ Yes National Environmental Department } & \multicolumn{2}{|l|}{ No N/A } \\
\hline Provincial government & \multicolumn{2}{|c|}{ Yes Provincial Development Agency } & \multicolumn{2}{|c|}{ Yes Provincial Conservation Department } \\
\hline Local government & \multicolumn{2}{|c|}{ Yes Local Municipality } & \multicolumn{2}{|c|}{ Yes Local Municipality } \\
\hline Private business interests & \multicolumn{2}{|c|}{ Yes Hotel representative, horse trail guide } & \multicolumn{2}{|l|}{ No N/A } \\
\hline Nongovernmental organizations & \multicolumn{2}{|l|}{ No N/A } & \multicolumn{2}{|c|}{$\begin{array}{l}\text { Yes Wildlife and Environmental Society of South } \\
\text { Africa }\end{array}$} \\
\hline Community representatives & \multicolumn{2}{|l|}{ Yes Umngazi Community } & \multicolumn{2}{|c|}{ Yes Tyolomnqa Community } \\
\hline Tribal authorities & \multicolumn{2}{|l|}{ No N/A } & \multicolumn{2}{|c|}{ N/A N/A } \\
\hline Research/academic institutions & \multicolumn{2}{|l|}{$\begin{array}{l}\text { Yes Two South African Ur } \\
\text { Research Commission }\end{array}$} & \multicolumn{2}{|c|}{$\begin{array}{l}\text { Yes South African University, Water Research } \\
\text { Commission }\end{array}$} \\
\hline $\begin{array}{l}\text { Step 1: Possible estuary-based enterprises } \\
\text { (where there is high supply and low } \\
\text { demand, low supply and high demand, or } \\
\text { high supply and high demand for services) }\end{array}$ & \multicolumn{2}{|c|}{$\begin{array}{l}\text { Bird watching, Block making, Restaurant, Bee } \\
\text { keeping, Crayfish factory, Sand mining, Craft } \\
\text { production, Horse trails, Canoe trails, } \\
\text { Village accommodation (as part of a destination } \\
\text { package), } \\
\text { Labor intensive government funded estuary } \\
\text { rehabilitation program }\end{array}$} & \multicolumn{2}{|c|}{$\begin{array}{l}\text { Seaweed harvesting, Residential settlements, Fishing, } \\
\text { Boating, Canoeing (races and recreational), Wilderness } \\
\text { camp, Brick making, } 4 \mathrm{X} 4 \text { trails }\end{array}$} \\
\hline $\begin{array}{l}\text { Steps } 2 \text { and 3: Priority enterprises } \\
\text { determined through discussion on current, } \\
\text { desired and conflicting roles }\end{array}$ & \multicolumn{2}{|c|}{$\begin{array}{l}\text { Canoe trails, Horse trails, Village-based tourist } \\
\text { accommodation, Labor intensive government funded } \\
\text { estuary rehabilitation program }\end{array}$} & \multicolumn{2}{|c|}{ Boating, $4 \mathrm{X} 4$ trails, Wilderness camp } \\
\hline \multirow{6}{*}{$\begin{array}{l}\text { Step 4: Chosen enterprise for risk } \\
\text { assessment }\end{array}$} & \multicolumn{2}{|c|}{ Village-based tourist accommodation } & \multicolumn{2}{|l|}{ Wilderness Camp } \\
\hline & Main risks & Mitigation & Main risks & Mitigation \\
\hline & $\begin{array}{l}\text { Communication } \\
\text { difficulties }\end{array}$ & $\begin{array}{l}\text { Establish internet } \\
\text { linkages with the nearby } \\
\text { established hotel }\end{array}$ & $\begin{array}{l}\text { Intensity of users is } \\
\text { controlled by provincial } \\
\text { and national government } \\
\text { departments that lack } \\
\text { regulating capacity }\end{array}$ & $\begin{array}{l}\text { Improve regulatory } \\
\text { capacity of provincial and } \\
\text { national government } \\
\text { departments. However this } \\
\text { is unlikely to occur in the } \\
\text { short term }\end{array}$ \\
\hline & $\begin{array}{l}\text { Because tourists like } \\
\text { being close to the beach, } \\
\text { communities located } \\
\text { inland are less likely to } \\
\text { benefit from tourists }\end{array}$ & $\begin{array}{l}\text { Sell a package that } \\
\text { includes visiting the } \\
\text { beach }\end{array}$ & $\begin{array}{l}\text { Poor legislation } \\
\text { implementation has } \\
\text { resulted in poor water } \\
\text { quality standards because } \\
\text { of informal settlements } \\
\text { being located near the } \\
\text { estuary, and the nearby } \\
\text { waste water treatment } \\
\text { works not being } \\
\text { adequately maintained }\end{array}$ & $\begin{array}{l}\text { Improve maintenance of } \\
\text { waste water treatment } \\
\text { works and establish formal } \\
\text { sanitation for the informal } \\
\text { settlements. However, } \\
\text { limited funds are available }\end{array}$ \\
\hline & \multirow[t]{2}{*}{$\begin{array}{l}\text { Declining quality of } \\
\text { attractions due to sand } \\
\text { mining }\end{array}$} & \multirow[t]{2}{*}{$\begin{array}{l}\text { Improve community } \\
\text { awareness of the } \\
\text { importance of a healthy } \\
\text { ecosystem, and the long- } \\
\text { term consequences if } \\
\text { sand mining continue }\end{array}$} & $\begin{array}{l}\text { Access to the estuary is } \\
\text { limited and security is } \\
\text { poor }\end{array}$ & $\begin{array}{l}\text { Remove illegal fencing } \\
\text { along the estuary and } \\
\text { improve security presence. } \\
\text { However, limited funds are } \\
\text { available for these } \\
\text { operations }\end{array}$ \\
\hline & & & $\begin{array}{l}\text { Approximately } 50 \% \text { of } \\
\text { the river has been } \\
\text { transformed and as a } \\
\text { result bank stabilization } \\
\text { for development has } \\
\text { caused habitat } \\
\text { destruction }\end{array}$ & $\begin{array}{l}\text { Municipality to take back } \\
\text { control of the banks and } \\
\text { rehabilitate. However, } \\
\text { limited funds are available } \\
\text { for this operation }\end{array}$ \\
\hline
\end{tabular}

questions, discussions around the different questions and between the different stakeholders were encouraged to gain a greater understanding of the SES, and especially to enable different stakeholders to understand each other's perspective. This helped address criteria 1, 2, and 4 .
In an effort to promote inclusivity at the workshops, when one stakeholder group dominated a response the facilitator would directly ask the other stakeholder groups whether or not they agreed with the dominant stakeholder group's viewpoint. This promoted discussion, ensured all participated, and helped gain 
a shared understanding of a situation. At both sites the provincial level planning authorities were generally more dominant and enthusiastic in comparison to other stakeholders. At Umngazi the provincial level authorities showed a keen interest in the indigenous knowledge communicated by the local community, and frequently asked for the community to expand on information when they did not initially grasp what was being said.

Step 1 of the toolkit, which took place at the beginning of the workshops and forced the stakeholders to work together to collectively ascribe scores, significantly contributed to the positive interactions that were observed between the stakeholders for the duration of the workshop. These good relations were most valued when populating the risk assessment and potentially sensitive issues needed to be discussed, e.g., the local community at Umngazi had to explain that there was a lack of service delivery from local government.

Although some discussions were very technical and difficult for all to understand, e.g., at Umngazi the community members struggled with understanding data presented by a university student researching estuarine benthic organisms, this lack of understanding did not cause resentment, but was in fact a source of amusement for all when scientific information was explained, which helped connect the stakeholders. At Umngazi this positive response to knowledge sharing was confirmed when after the workshop the community told the facilitator that the toolkit had "opened their eyes to the importance of the estuary, how it worked, and the opportunities it held."

Through implementing Step 1 at the Umngazi estuary, a total of 12 possible estuary-based enterprises were identified. Through implementing the subsequent steps, four were identified as priority enterprises (Table 5). The village-based tourist accommodation, as part of a destination package, was selected for the risk assessment because the consensus of the stakeholders was that this enterprise would benefit a greater proportion of the community compared with the canoe and horse trails. In addition, the success of the accommodation enterprise predominantly rested with the community and the management of the well-established and successful hotel, thus its success was semicontrolled by the stakeholders. Although an estuary rehabilitation program (labor intensive alien plant removal), which the provincial level planning authorities were initially favoring, has the potential to result in a larger cash injection into the community in the short-term, similar programs have been established in the area and, because of inconsistent implementation, the community was wary of these types of enterprises. Although a number of risks were identified for the accommodation, possible actions to reduce these risks were provided (Table 5).
Through implementing Step 1 at the Tyolomnqa estuary, a total of eight possible estuary-based enterprises were identified. In working through the remaining steps there was consensus between the stakeholders that a wilderness camp would be used in Step 4 (Table 5). A wilderness camp at Tyolomnqa had previously failed, and the attendees were keen to know the reason for its failure, and if any mitigation measures could be implemented to improve its chances of survival if it was resuscitated.

It was concluded that the identified risks were of a magnitude that could not be mitigated or easily controlled without a combination of improved regulatory capacity and the sourcing of alternative nonmunicipal funds. Because the potential for implementing these two mitigation measures could not be accurately assessed with only those in attendance, the wilderness camp was not pursued further.

When the risk assessment concludes that an enterprise does not show potential resilience, the risk assessment can be repeated to assess an alternative enterprise. However, in this instance the identified risks at Tyolomnqa, which includes a lack of regulating capacity, poor water quality standards, habitat destruction, limited access, and poor security, are likely to affect the supply of the services on which any estuary enterprise is based. The risk assessment highlighted to the provincial planning authority representatives at the workshop, that to give an estuary-based enterprise the greatest chance of survival, some or all of the identified risks should be addressed before any new enterprise is pursued.

The provincial planning authority at Tyolomnqa could see value in the approach and in reflecting on a potential wider application. They were of the opinion that the toolkit could be:

- run for each estuary in the province to compare and highlight which estuaries offer the highest service levels, and thus where development should be focused;

- used to match activities to the most appropriate estuary, because implementing the toolkit effectively revealed how different activities were matched to the estuary;

- used to guide policy making and demonstrate the need for compliance because the implementation of the toolkit highlighted specific policy needs for the estuary, e.g., development control, and where the greatest specific needs were for compliance, e.g., water quality.

At both sites the use of numerical values as relative measures in the toolkit helped to objectively select which enterprises should be selected for the risk assessment, because the scores were ascribed with consensus from the stakeholders in attendance. Having a broad scope of enterprises that need to be scored helped prevent the stakeholders getting fixated on one particular enterprise. In addition, numerical illustration 
steered discussions toward obtaining relevant qualitative data, thus time was not lost on irrelevant discussions.

In summary, the workshops identified that there are significant opportunities for the establishment of estuary-based enterprises that could act as catalysts for economic empowerment. However, currently the public service infrastructure providers, primarily local government, are either unwilling or unable to provide the necessary support required to improve the likelihood of an estuary-based enterprise being resilient. It is here where the major risks lie.

The purpose of the toolkit is to help identify potential resilient enterprises. Although all four steps within the toolkit contribute to identifying potential resilient enterprises, it is Step 4 (risk assessment) where the resilience of an enterprise is gauged. Thus the implementation of the risk assessment contributed toward addressing criterion 3 .

\section{DISCUSSION}

In this section we consider application of the toolkit in view of the four criteria in Turner and Daily's (2008) critique.

\section{An ESF Toolkit for economic empowerment must be participative}

The first constraint identified by Turner and Daily (2008) was that of information failure. The toolkit addresses this constraint because it is participant-focused and promotes direct communication between the different stakeholders, some of whom are decision makers. The toolkit combines both a generic top-down scientific approach, because the preprogrammed worksheet and risk assessment are founded on theory and scientific knowledge, with a case-specific bottom-up approach, which is obtained through a diversity of stakeholders actively engaging in discussion and reaching consensus on the scoring of the supply and demand of ecosystems services at a site-specific level. A facilitator is required to collate, interpret, and concisely present the information from the workshops, but this nevertheless represents a process aimed at bringing indigenous knowledge and science together to foster social-ecological system resilience (Bohensky and Maru 2011).

This extent of dialogue clearly results in better decisions being made. For example, at the Umngazi study site, the results of implementing the ESF Framework indicated that an estuary rehabilitation program would have created greater economic advantages compared with the community-based accommodation. However the community was strongly against this type of enterprise because similar initiatives had failed in the past. It is likely that without the participation of the community and the testing of the toolkit, decision makers would have pursued the estuary rehabilitation program. Based on the negative reactions of the community, it is likely that this enterprise would not have been supported.
Through applying the toolkit a number of participatory lessons were learned. These lessons have been tabulated and have been grouped into (i) facilitator; (ii) stakeholder; and (iii) workshop procedure lessons (Table 6). Bohensky and Maru (2011) have recently reviewed the challenges and achievements in bringing indigenous knowledge and science together and a number of key lessons presented in Table 2 of Bohensky and Maru (2011) could also assist the facilitator with implementing the toolkit in the future.

\section{An ESF Toolkit for economic empowerment must provide} detailed information on ecosystem services

The toolkit provides a systematic process for obtaining both qualitative and semiquantitative information, and a shared understanding of the way in which stakeholders benefit from ecosystem services. At Umngazi this mutual understanding is likely to help improve the resilience of the community-based accommodation enterprise because the stakeholders understood why this particular enterprise had been chosen and what services were required for it to be successful. It is likely that with the depth of understanding gained through implementing the toolkit, those in decision making positions, e.g., government officials, will help to ensure the protection of the ecosystems on which the community-based accommodation is reliant, e.g., basic infrastructure to service the accommodation, electricity, water, access road.

The second constraint identified by Turner and Daily (2008) was that of institutional failure. Before the workshop at the Tyolomnqa estuary, the provincial planning authority was of the opinion that there were likely to be many estuary-based enterprise opportunities because of the estuary being utilized for a wide range of activities and by a relatively high number of people. However, the risk assessment highlighted a wide range of constraints of which the provincial planning authority was previously unaware. This emphasizes the value of the toolkit in promoting discussion based on structured consideration of ecosystem services.

The third constraint identified by Turner and Daily (2008) was that of market failure. Although there is neither a universal currency to value the services provided by the estuary, nor quantification of services in currency terms, the use of relative scoring allowed services to be given nominal values to facilitate comparisons to be made.

\section{An ESF Toolkit for economic empowerment must consider resilience}

The collated data on the supply and demand of the ecosystem services highlighted to all stakeholders at both study sites that the estuary is a common pool that is utilized by many. Because the toolkit promotes a shared understanding of the resource and of resource users, enterprises that do not affect or have limited impact on the availability of the services used by other resource users, and vice versa, were identifiable. This 
Table 6. Participatory lessons learned from applying the toolkit.

Lessons for facilitators

- $\quad$ Because application of the toolkit can take considerable time, facilitators must be able to stimulate communication between stakeholders and keep discussion strategic. Because implementing the toolkit is intellectually demanding for both facilitators and stakeholders, short sessions and long breaks are recommended.

- $\quad$ Because of a variety of stakeholders participating in the toolkit, it is beneficial for facilitators to have previous experience with implementing participatory tools and communication methods with a range of stakeholder type (Bradshaw and Bekoff 2001, Kinzig 2001).

- $\quad$ Because one type of enterprise may be beneficial to one group of stakeholders but detrimental to another, e.g., the establishment of village-based accommodation will benefit some community members, however the hotel may lose bed nights, facilitators must take into consideration possible hidden agendas, e.g., economic interests (Kenney 1999).

- $\quad$ Some stakeholders dominate discussions more than others. Thus, facilitators should be aware of personal characteristics of the different stakeholders, because these can have a significant influence on the information that populates the toolkit (Jakobsen et al. 2004, Lyman et al. 2007).

- Having a wide variety of stakeholders participating, e.g., National Government, community hiking guides, can result in an imbalance of power among the stakeholders (McCloskey 1996, Lyman et al. 2007). Only facilitators can address this issue, because the tools by themselves are not able to (Lyman et al. 2007). One method to combat this bias is to introduce quality control methods, such as cross-checking by asking the same questions in a multiple of ways (Lyman et al. 2007).

- $\quad$ Facilitators should be confident and able to inspire confidence among the stakeholders.

Lessons for stakeholders

- $\quad$ The accuracy of the data obtained from the toolkit is dependent on the representativeness of the stakeholder groups at the workshops.

- It is imperative that people who are actively involved with currently established local enterprises are involved in the SES. However most successful businessmen are unable to engage in these processes because they are too busy and that is why they are successful.

- $\quad$ Trust must be established between the stakeholders. Trust can only be achieved if (i) all stakeholders put their egos aside; (ii) workshops have a patient facilitator; and (iii) stakeholders are given sufficient time to get to know and understand each other (Deconchat et al. 2007).

- $\quad$ Two workshops were held at Umngazi approximately five months apart. Because the toolkit involved stakeholder engagement over a prolonged period of time, problems arose with new stakeholders joining the second workshop, and dominant stakeholders not being present at the second workshop, e.g., Provincial Government officials transferred between different provinces. These changes led to: (i) time needed to be spent on regaining trust between the participants; (ii) previous discussions having to be repeated, which was time-consuming; and (iii) newcomers not agreeing with consensus views obtained from the previous workshop. To address this, a continuous effort must be made between the stakeholders to ensure collective coherence (Roybin et al. 2001).

- If unexpected or conflicting information is given by a stakeholder, clarification must be sought, because this can highlight incorrect assumptions and provide new insights (Sheil and Liswanti 2007).

Lessons for workshop procedures

- Because the success of implementing the toolkit is based on mutual trust, it is important that before conducting the workshop, the facilitator makes clear what the purpose of the toolkit is, and what can be achieved (Sturtevant et al. 2007).

- $\quad$ All stakeholders should feel included and equally valued, thus the workshops must be conducted so that all those present can understand what is being discussed and, if necessary, methods must be employed to overcome language and literacy barriers. Language must be kept as simple and concise as possible, and concepts should be illustrated through locally relevant examples. If a common language is not possible, translators must be used. When a language barrier is present, the success of the toolkit is reliant on the skill level of the translator.

knowledge is the foundation for identifying resilient enterprises.

The toolkit has demonstrated that it can be used to help identify potential estuary-based enterprises that can function under current ecosystem service supply and demand conditions. However supply and demand are constantly changing and for an enterprise to have the greatest chance of being resilient, it must be adaptable. The adaptability of an enterprise, i.e., ability of the enterprise to be managed for resilience, is difficult to gauge without an enterprise first being established. The adaptability of an enterprise is human driven and this highlights a gap in the toolkit. For an enterprise to be resilient, it must be resilient at an external SES level, which the toolkit addresses, and at an internal business functioning level, which includes social dynamics among personnel, skills, and literacy levels. Furthermore, as noted by Coulthard (2012), fundamental questions still remain around the equity of adaptation, i.e., how the gains and losses of adaptation in a resilient system are distributed within a society, and that improved resilience does not necessarily result in improved well-being of people.

Although the toolkit does not address the internal resilience of an enterprise, it does indicate which enterprises show potential resilience, given current SES conditions. Establishing whether or not an enterprise is resilient in terms of external SES conditions must always be done before an enterprise is established, for without external resilience, an internally resilient enterprise will still not succeed. If the internal operation of an enterprise is not resilient, for example if the market demands beach holidays and the holiday package is not being adapted to offer beach visits because of a lack of market knowledge, it is possible to educate personnel to 
provide this service. However, it is much more challenging to alter external level factors that impact on the supply and demand of ecosystem services, such as providing and maintaining access roads to the beach.

Although the toolkit was aimed at accommodating resilience, it does establish a level of common understanding that would enable a vulnerability assessment to be conducted. For example one could envisage leading from this application of the toolkit into a subsequent vulnerability assessment along the lines proposed by Ravera et al. (2011). Similarly, Cabell and Oelofse (2012) propose 13 behavior-based indicators that can be used to assess resilience and capacity for adaptation and transformation. Although developed with agroecosystems in mind the approach has obvious extensions to other SESs.

\section{An ESF Toolkit for economic empowerment must accommodate complex social-ecological contexts}

The greater the diversity of stakeholders attending and participating at a workshop, the greater the understanding of a complex SES. At both study sites there were a reasonable variety of stakeholders present. Although some stakeholders were more dominant than others, with good facilitation all participants contributed, and this resulted in a greater level of trust, respect, and knowledge sharing between stakeholders.

Although the degree to which a stakeholder understood the viewpoint of another stakeholder was not formally evaluated, by the end of the workshop the facilitator was confident that stakeholders had a good understanding of both the ecosystem services utilized by other stakeholder groups, and the complexities of the SES. Other than directly asking each stakeholder what they have learned, there is no other practical method for evaluating what information was absorbed by the different stakeholders. Although possible, this questioning would have added additional time to an already lengthy participatory process. Despite this shortcoming, there is little doubt that the process could be categorized as a good example of social learning. Keen et al. (2005:4) define social learning as the "collective action and reflection that occurs among different individuals and groups as the work to improve the management of human and environmental interrelations." McCarthy et al. (2011) have outlined a heuristic for describing the epistemological context for social learning within complex SES, and doubtless use of this in future applications of the toolkit would improve the quality of the social learning process.

In summary the participatory approach of the toolkit helped the stakeholders to gain a good understanding of the different perspectives of the other stakeholders, and importantly, the complex interdependencies of the SES. This is an important first step in enhancing resilience, adaptability, and transformability. More specifically this mutual understanding would improve the resilience of an enterprise, because it is likely that if the operating of an enterprise negatively impacts upon service delivery for another stakeholder, with greater shared understanding there may be more chance for compromise whereby both stakeholders continue to benefit from services supplied by the estuary. Moore and Westley (2011) have highlighted the importance of networks in relationship building and brokering, and knowledge and resource brokering and how this is fundamental to social innovation. They see this as key in improving human capacity to address challenging problems and improve resilience. In the context of the estuary project, it was clear that we were seeing the incipient formation of a network that if nurtured, could generate the 'institutional entrepreneurs' referred to by Moore and Westley (2011).

\section{Improvement to and further development of the toolkit}

The data extracted when implementing the toolkit is primarily derived from discussions among the different stakeholders attending the workshop. A shortcoming of the toolkit is that in its present form it does not explicitly encourage the sourcing of existing ecological, demographic, social, or market data. The integration of this data into the ESF Framework would considerably strengthen the toolkits scientific founding. Such data could include censuses, market analyses, (such as B. Reyers and E. Ginsburg, unpublished manuscript), and published biodiversity assessments (such as the National Biodiversity Assessment Database which shows the habitat areas and ecological health statuses of all South African estuaries, http://rava.qsens.net/themes/coastal template/nationalbiodiversity-assessment-2011-estuary-component/2011_NSB Apartial01.xlsx/view).

Because our findings are based primarily on estuarine SESs, and because ecosystems greatly differ in terms of species composition, service provision, and resilience thresholds (Scheffer et al. 2000), it is not possible to directly transfer this framework to other ecosystems, e.g., wetlands, grasslands, forests. However, given the fact that only Step 1 of the toolkit directly deals with ecosystem services and is tailored specifically to estuaries, the toolkit is likely to be readily adapted for other ecosystem types. The integration of relevant ecological data for other ecosystems is also recommended.

\section{CONCLUSION}

In summary this paper documents how the theory of the Anderies et al. (2004) framework has been translated into a practical toolkit that can be used by a diversity of stakeholders as a decision making aid for assessing ecosystem services supply and demand, and associated enterprise opportunities. Thus, the toolkit addresses the hiatus previously referred to by providing an operational decision support system for the practical integration of ecosystem services into decision making processes. In doing so the approach initiates a process of social learning, considered critical in enhancing resilience, adaptability, and transformability in complex SESs. 
Of course it is impossible to accurately predict if a proposed enterprise will be resilient or not, but the toolkit does however, provide a structured mechanism for identifying enterprises that have the potential to be resilient. At present the toolkit does not include steps to monitor the impacts of the enterprise on the receiving SES once established, or to assess the internal business functioning level of a particular enterprise. Additional work is required in these areas.

Responses to this article can be read online at:

http://www.ecologyandsociety.org/vol17/iss3/art15/

responses/

\section{Acknowledgments:}

Dr. Steve Mitchell of the South African Water Research Commission and Mr. Andrew Mather of eThekwini Municipality for their valuable input into the development of this toolkit. The participants of the Umngazi and Tyolomnqa workshops for sharing their knowledge. Funding for this project came from the South African Water Research Commission: Estuaries and Economic Empowerment project.

\section{LITERATURE CITED}

Allanson, B. R. 1981. The coastal lakes of southern Africa. Pages 331-344 in J. H. Day, editor. Estuarine ecology with particular reference to southern Africa. Balkema, Cape Town, South Africa.

Anderies, J. M. 2002. The transition from local to global dynamics: a proposed framework for agent-based thinking in socio-ecological systems. Pages 13-34 in M. A. Janssen, editor. Complexity and ecosystem management: the theory and practice of multi-agent systems. Edward Elgar, Cheltenham, UK.

Anderies, J. M., M. A. Janssen, and E. Ostrom. 2004. A framework to analyze the robustness of social-ecological systems from an institutional perspective. Ecology and Society 9(1): 18. [online] URL: http://www.ecologyandsociety.org/vol9/ iss1/art18/

Anderies, J. M., B. H. Walker, and A. P. Kinzig. 2006. Fifteen weddings and a funeral: case studies and resilience-based management. Ecology and Society 11(1): 21. [online] URL: http://www.ecologyandsociety.org/vol11/iss1/art21/

Baird, D. 1999. Estuaries as ecosystems: a functional and comparative analysis. Pages 269-288 in B. R. Allanson and D. Baird, editors. Estuaries of South Africa. Cambridge University Press, Cambridge, UK.

Baiyegunhi, L. J. S., and G. C. G. Fraser. 2010. Determinants of household poverty dynamics in rural regions of the Eastern Cape Province, South Africa. Paper presented at the 3rd
African Association of Agricultural Economists (AAAE) and 48th Agricultural Economists Association of South Africa (AEASA) Conference, Cape Town, South Africa, September 19-23, 2010. [online] URL: http://ageconsearch.umn.edu/bits tream/97078/2/63.\%20Poverty\%20dynamics\%20in\%20South\% 20Africa.pdf

Barbier, E. B., S. D. Hacker, C. Kennedy, E. W. Koch, A. C. Stier, and B. R. Silliman. 2011. The value of estuarine and coastal ecosystem services. Ecological Monographs 81 (2):169-193. http://dx.doi.org/10.1890/10-1510.1

Batabyal, A. A., and S. J. Yoo. 1994. Renewal theory and natural resource regulatory policy under uncertainty. Economics Letters 46:237-241. http://dx.doi.org/10.1016/016 5-1765(94)00474-9

Baumgärtner, S., S. Derissen, M. F. Quaas, and S. Strunz. 2011. Consumer preferences determine resilience of ecological-economic systems. Ecology and Society 16(4): 9. http://dx.doi.org/10.5751/ES-04392-160409

Berkes, F. 1999. Sacred ecology: traditional ecological knowledge and resource management. Taylor \& Francis, London, UK.

Berkes, F., C. Folke, and J. Colding. 1998. Linking social and ecological systems: management practices and social mechanisms for building resilience. Cambridge University Press, New York, New York, USA.

Bohensky, E. L., and Y. Maru. 2011. Indigenous knowledge, science, and resilience: what have we learned from a decade of international literature on "integration"? Ecology and Society 16(4): 6. http://dx.doi.org/10.5751/ES-04342-160406

Bowd, R., C. Breen, D. Hay, D. Kotze, and M. Mander. 2012. An approach to estuary-based economic empowerment with a particular focus on the Eastern Cape Wild Coast. WRC Report No. 1705/1/11. Water Research Commission, Pretoria, South Africa.

Bradshaw, G. A., and M. Bekoff. 2001. Ecology and social responsibility: the re-embodiment of science. Trends in Ecology \& Evolution 16:460-465. http://dx.doi.org/10.1016/S 0169-5347(01)02204-2

Branch, G. M., and J. R. Grindley. 1979. Ecology of Southern African estuaries. Part XI. Mngazana: a mangrove estuary in Transkei. South African Journal of Zoology 14:149-170.

Brown, K., T. Daw, S. Rosendo, M. Bunce, and N. Cherrett. 2008. Ecosystem services for poverty alleviation: marine and coastal situational analysis. Synthesis report produced and submitted to the Ecosystem Services and Poverty Alleviation Research Programme, Economic \& Social Research Council, Department for International Development, Natural Environment Research Council, Swindon, UK. [online] URL: 
http://www.nerc.ac.uk/research/programmes/espa/documents/ Marine\%20and\%20Coastal\%20-\%20Synthesis\%20Report.pdf

Bures, R., and W. Kanapaux. 2011. Historical regimes and social indicators of resilience in an urban system: the case of Charleston, South Carolina. Ecology and Society 16(4): 16. http://dx.doi.org/10.5751/ES-04293-160416

Cabell, J. F., and M. Oelofse. 2012. An indicator framework for assessing agroecosystem resilience. Ecology and Society 17(1): 18. http:dx.doi.org/10.5751/ES-04666-170118

Carpenter, S., B. Walker, J. M. Anderies, and N. Abel. 2001. From metaphor to measurement: resilience of what to what? Ecosystems 4:765-781. http://dx.doi.org/10.1007/s10021-001 $\underline{-0045-9}$

Colloty, B. M., J. B. Adams, and G. C. Bate. 2002. Classification of estuaries in the Ciskei and Transkei regions based on physical and botanical characteristics. South African Journal of Botany 68:312-321.

Costanza, R., and C. Folke. 1997. Valuing ecosystem services with efficiency, fairness, and sustainability as goals. Pages 49-68 in G. C. Daily, editor. Nature's services. Island Press, Washington, D.C., USA.

Coulthard, S. 2012. Can we be both resilient and well, and what choices do people have? Incorporating agency into the resilience debate from a fisheries perspective. Ecology and Society 17(1): 4. http://dx.doi.org/10.5751/ES-04483-170104

Daily, G. C., and P. A. Matson. 2008. Ecosystem services: from theory to implementation. Proceedings of the National Academy of Sciences of the United States of America 105 (28):9455-9456. http://dx.doi.org/10.1073/pnas.0804960105

Day, J. H. 1980. What is an estuary? South African Journal of Science 76:198.

Deconchat, M., A. Gibon, A. Cabanettes, G. du Bus de Warnaffe, M. Hewison, E. Garine, A. Gavaland, J.-P. Lacombe, S. Ladet, C. Monteil, A. Ouin, J.-P. Sarthou, A. Sourdril, and G. Balent. 2007. How to set up a research framework to analyze social-ecological interactive processes in a rural landscape. Ecology and Society 12(1): 15. [online] URL: http://www.ecologyandsociety.org/vol12/iss1/art15/

de Groot, R. S., M. A. Wilson, and R. M. J. Bouman. 2002. A typology for the classification, description and valuation of ecosystem services, goods and services. Ecological Economics 41:393-408. http://dx.doi.org/10.1016/S0921-8009 $\underline{(02) 00089-7}$

Dzivakwi, R., and P. T. Jacobs. 2010. Support for pro-poor agricultural development and rural poverty reduction in Eastern Cape. Paper presented at the 3rd African Association of Agricultural Economists (AAAE) and 48th Agricultural Economists Association of South Africa (AEASA) Conference, Cape Town, South Africa, September 19-23, 2010. [online] URL: http://ageconsearch.umn.edu/bitstream/96808/2/183.\% 20Agriculture $\% 20$ in $\% 20$ the $\% 20 \mathrm{E} \% 20 \mathrm{Cape} \% 20 \mathrm{in} \% 20$ South $\%$ 20Afica.pdf

Fall, A., and J. Fall. 2001. A domain-specific language for models of landscape dynamics. Ecological Modelling 141:1-18. http://dx.doi.org/10.1016/S0304-3800(01)00334-9

Fazey I., J. A. Fazey, and D. M. A. Fazey. 2005. Learning more effectively from experience. Ecology and Society 10(2): 4. [online] URL: http://www.ecologyandsociety.org/vol10/iss2/ $\underline{\operatorname{art} 4 /}$

Folke, C., S. Carpenter, B. Walker, M. Scheffer, T. Elmqvist, L. Gunderson, and C. S. Holling. 2004. Regime shifts, resilience, and biodiversity in ecosystem management. Annual Review of Ecology, Evolution and Systematics 35:557-581. http://dx.doi.org/10.1146/annurev.ecolsys.35.021103.105711

Folke, C., S. R. Carpenter, B. Walker, M. Scheffer, T. Chapin, and J. Rockström. 2010. Resilience thinking: integrating, resilience, adaptability and transformability. Ecology and Society 15(4): 20. [online] URL: http://www.ecologyandsociety. org/vol15/iss4/art20/

Folke, C., T. Hahn, P. Olsson, and J. Norberg. 2005. Adaptive governance of social-ecological systems. Annual Review of Environment and Resources 30:441-473. http://dx.doi.org/10 .1146/annurev.energy.30.050504.144511

Fosu, A. K. 2011. Growth, inequality and poverty reduction in developing countries: recent global evidence. Working Paper No 147. Brooks World Poverty Institute, Manchester, UK. http://dx.doi.org/10.2139/ssrn.1813968

Granek, E. F., S. Polasky, C. V. Kappel, D. J. Reed, D. M. Stoms, E. W. Koch, C. J. Kennedy, L. A. Cramer, S. D. Hacker, E. B. Barbier, S. Aswani, M. Ruckelshaus, G. M. E. Perillo, B. R. Silliman, N. Muthiga, D. Bael, and E. Wolanski. 2009. Ecosystem services as a common language for coastal ecosystem-based management. Conservation Biology 24 (1):207-216. http://dx.doi.org/10.1111/j.1523-1739.2009.01355. $\underline{\mathrm{X}}$

Grimm, V., and C. Wissel. 1997. Babel, or the ecological stability discussions: an inventory and analysis of terminology and a guide for avoiding confusion. Oecologia 109:323-334. http://dx.doi.org/10.1007/s004420050090

Gunderson, L. H. 2001. South Florida: the reality of change and the prospects for sustainability: managing surprising ecosystems in Southern Florida. Ecological Economics 37:371-378. http://dx.doi.org/10.1016/S0921-8009(01)00179-3 
Gunderson, L. H, S. R. Carpenter, C. Folke, P. Olsson, and G. Peterson. 2006. Water RATs (resilience, adaptability, and transformability) in lake and wetland social-ecological systems. Ecology and Society 11(1): 16. [online] URL: http:// www.ecologyandsociety.org/vol11/iss1/art16/

Gunderson, L. H., and C. S. Holling, editors. 2002. Panarchy: understanding transformations in human and natural systems. Island Press, Washington, D.C., USA.

Hay, D., editor. 2007. Profiling estuary management in integrated development planning in South Africa with particular reference to the Eastern Cape Province. WRC Report No. 1484/1/07. Water Research Commission, Pretoria, South Africa.

Hein, L., K. van Koppen, R. S. de Groot, and E. C. van Ierland. 2006. Spatial scales, stakeholders and the valuation of ecosystem services. Ecological Economics 57:209-228. http: //dx.doi.org/10.1016/j.ecolecon.2005.04.005

Holling, C. S. 2010. Engineering resilience versus ecological resilience. Pages 51-66 in L. H. Gunderson, C. R. Allen, C. S. Holling, editors. Foundations of ecological resilience. Island Press, Washington, D.C., USA.

Hughes, T. P., D. R. Bellwood, C. Folke, R. S. Steneck, and J. Wilson. 2005. New paradigms for supporting the resilience of marine ecosystems. Trends in Ecology \& Evolution 20 (7):380-386. http://dx.doi.org/10.1016/j.tree.2005.03.022

Hunter, N., J. May, and V. Padayachee. 2003. Lessons for PRSP from poverty reduction strategies in South Africa. Third meeting of the African learning group on the poverty reduction strategy papers, 3-5 December 2000, Addis Ababa, Ethiopia. Economic Commission for Africa, Addis Ababa, Ethiopia.

Jakobsen, C. H., T. Hels, and W. J. McLaughlin. 2004. Barriers and facilitators to integration among scientists in transdisciplinary landscape analysis: a cross-country comparison. Forest Policy and Economics 6:15-31. http://dx. doi.org/10.1016/S1389-9341(02)00080-1

Janssen, M. A., J. M. Anderies, and B. H. Walker. 2004. Robust strategies for managing rangelands with multiple stable attractors. Journal of Environmental Economics and Management 47:140-162. http://dx.doi.org/10.1016/S0095-0696 (03)00069-X

Keen, M., V. A. Brown, and R. Dyball. 2005. Societal learning in environmental management: towards a sustainable future. Earthscan, London, UK.

Kenney, D. S. 1999. Are community-based watershed groups really effective? Confronting the thorny issue of measuring success. Chronicle of Community 2(3):33-38.

Kinzig, A. P. 2001. Bridging disciplinary divides to address environmental and intellectual challenges. Ecosystems 4:709-715. http://dx.doi.org/10.1007/s10021-001-0039-7
Leemans, R. 2000. Modelling of global land use: connections, causal chains and integration. Inaugural lecture, Department of Plant Production Systems, Wageningen University, Wageningen, The Netherlands.

Leibbrandt, M., I. Woolard, A. Finn, and J. Argent. 2010. Trends in South African income distribution and poverty since the fall of apartheid. OECD Social, Employment and Migration Working Papers, No 101. Organisation for Economic Co-operation and Development, Paris, France. htt p://dx.doi.org/10.1787/5kmms0t7p1ms-en

Lynam, T., W. De Jong, D. Sheil, T. Kusumanto, and K. Evans. 2007. A review of tools for incorporating community knowledge, preferences, and values into decision making in natural resources management. Ecology and Society 12(1): 5. [online] URL: http://www.ecologyandsociety.org/vol12/iss1/ $\underline{\operatorname{art5/}}$

McCarthy, D. D. P., D. D. Crandall, G. S. Whitelaw, Z. General, and L. J. S. Tsuji. 2011. A critical systems approach to social learning: building adaptive capacity in social, ecological, epistemological (SEE) systems. Ecology and Society 16(3): 18. http://dx.doi.org/10.5751/ES-04255-160318

McCloskey, M. 1996. The skeptic: collaboration has its limits. High Country News, 13 May. [online] URL: http://www.hen. org/servlets/hcn.Article?article id=1839

Meth, C., and R. and Dias. 2004. Increases in poverty in South Africa, 1999-2002. Development Southern Africa 21:59-85. http://dx.doi.org/10.1080/0376835042000181426

Millennium Ecosystem Assessment (MEA). 2003. Ecosystems and human well-being: a framework for assessment. Report of the Conceptual Framework Working Group of the Millennium Ecosystem Assessment. Island Press, Washington, D.C., USA.

Millennium Ecosystem Assessment (MEA). 2005. Millennium Ecosystem Assessment: ecosystems and human well-being synthesis. Island Press, Washington, D.C., USA.

Moore, M., and F. Westley. 2011. Surmountable chasms: networks and social innovation for resilient systems. Ecology and Society 16(1): 5. [online] URL: http://www.ecologyands ociety.org/vol16/iss1/art5/

Neubert, M. G., and H. Caswell. 1997. Alternatives to resilience for measuring the responses of ecological systems to perturbations. Ecology 78:653-665. http://dx.doi.org/10.18 90/0012-9658(1997)078[0653:ATRFMT]2.0.CO;2

Newton, A. C. 2011. Social-ecological resilience and biodiversity conservation in a 900-year-old protected area. Ecology and Society 16(4): 13. http://dx.doi.org/10.5751/ES$\underline{04308-160413}$

Olsson, P., C. Folke, and F. Berkes. 2004. Adaptive comanagement for building resilience in social-ecological 
systems. Environmental Management 34:75-90. http://dx.doi. org/10.1007/s00267-003-0101-7

Ostrom, E. 2007. A diagnostic approach for going beyond panaceas. Proceedings of the National Academy of Sciences of the United States of America 104(39):15181-15187. http:// dx.doi.org/10.1073/pnas.0702288104

Pearce, D. W., and R. K. Turner. 1990. Economics of natural resources and the environment. Harvester Wheatsheaf, Harlow, UK.

Pickett, S. T. A., W. R. Burch, and J. M. Grove. 1999. Interdisciplinary research: maintaining the constructive impulse in a culture of criticism. Ecosystems 2(4):302-307. http://dx.doi.org/10.1007/s100219900081

Pimm, S. L. 1991. The balance of nature? Ecological issues in the conservation of species and communities. University of Chicago Press, Chicago, Illinois, USA.

Ravera, F., D. Tarrasón, and E. Simelton. 2011. Envisioning adaptive strategies to change: participatory scenarios for agropastoral semiarid systems in Nicaragua. Ecology and Society 16(1): 20. [online] URL: http://www.ecologyandsociety. org/vol16/iss1/art20

Resilience Alliance. 2010. Assessing resilience in socialecological systems: workbook for practitioners. Version 2.0. [online] URL: http://www.resalliance.org/3871.php

Roybin, D., P. Fleury, C. Béranger, and D. Curtenaz. 2001. Conduite de recherches pluridisciplinaires en partenariat et apprentissages collectifs. Le cas du GIS Aples du Nord. Nature Sciences Sociétés 9(3):16-28. http://dx.doi.org/10.1016/S124 $\underline{0-1307(01) 89045-2}$

Scheffer, M., W. Brock, and F. Westley. 2000. Socioeconomic mechanisms preventing optimum use of ecosystem services: an interdisciplinary theoretical analysis. Ecosystems 3:451-471. http://dx.doi.org/10.1007/s100210000040

Shackleton, C., S. Shackleton, J. Gazimba, E. Nel, K. Rowntree, and P. Urquhart. 2008. Links between ecosystem services and poverty alleviation: situation analysis for arid and semi-arid lands in southern Africa. Consortium on Ecosystems and Poverty in Sub-Saharan Africa (CEPSA) submission to the Ecosystem Services and Poverty Reduction Research Programme, Economic \& Social Research Council, Department for International Development, Natural Environment Research Council, Swindon, UK. [online] URL: http://www.unpei.org/PDF/preliminaryassessments/Links-EcosystemServices-and-Poverty-Alleviation.pdf

Sheil, D., and N. Liswanti. 2007. Scoring the importance of tropical forest landscapes with local people: patterns and insight. Environmental Management 38(1):126-136. http://dx. doi.org/10.1007/s00267-005-0092-7
Sturtevant, B. R., A. Fall, D. D. Kneeshaw, N. P. P. Simon, M. J. Papaik, K. Berninger, F. Doyon, D. G. Morgan, and C. Messier. 2007. A toolkit modeling approach for sustainable forest management planning: achieving balance between science and local needs. Ecology and Society 12(2): 7. [online] URL: http://www.ecologyandsociety.org/vol12/iss2/art7/

Tallis, H., K. Kareiva, M. Marvier, and A. Chang. 2008. An ecosystem services framework to support both practical conservation and economic development. Proceedings of the National Academy of Sciences of the United States of America 105(28):9457-9464. http://dx.doi.org/10.1073/pnas.0705797105

Turner, R. K., and G. C. Daily. 2008. The ecosystem services framework and natural capital conservation. Environmental and Resource Economics 39:25-35. http://dx.doi.org/10.1007/ $\underline{\mathrm{s} 10640-007-9176-6}$

Turpie, J., and B. Clark. 2007. Development of a conservation plan for temperate South African estuaries on the basis of biodiversity importance, ecosystem health and economic costs and benefits. Report prepared for the CAPE Regional Estuarine Management Programme, Rondebosch, South Africa.

Walker B., S. Carpenter, J. Anderies, N. Abel, G. S. Cumming, M. Janssen, L. Lebel, J. Norberg, G. D. Peterson, and R. Pritchard. 2002. Resilience management in social-ecological systems: a working hypothesis for a participatory approach. Conservation Ecology 6(1): 14. [online] URL: http://www.co nsecol.org/vol6/iss 1/art14

Walker, B., C. S. Holling, S. R.. Carpenter, and A. Kinzig. 2004. Resilience, adaptability and transformability. Ecology and Society 9(2): 5. [online] URL: http://www.ecologyandso ciety.org/vol9/iss $2 /$ art5

Walker, B. H. 1992. Biodiversity and ecological redundancy. Conservation Biology 6:18-23. http://dx.doi.org/10.1046/j.15 23-1739.1992.610018.x

Walker, B. H., J. M. Anderies, A. P. Kinzig, and P. Ryan. 2006. Exploring resilience in social-ecological systems through comparative studies and theory development: introduction to the special issue. Ecology and Society 11(1): 12. [online] URL: http://www.ecologyandsociety.org/vol11/iss1/ $\underline{\operatorname{art} 12 /}$

Westley, F., S. R. Carpenter, W. A. Brock, C. S. Holling, and L. Gunderson. 2002. Why systems of people and nature are not just social and ecological systems. Pages 103-119 in L. H. Gunderson and C. S. Holling, editors. Panarchy: understanding transformation in human and natural systems. Island Press, Washington, D.C., USA. 